\title{
Obituary
}

\section{In Celebration of the Life of Shaykh Taha Jabir al-'Alwani}

\section{May 12, 1935 - March 4, 2016}

Shaykh Taha Jabir al-'Alwani - professor of jurisprudence (fiqh) and the principles of jurisprudence (ușūl al-fiqh); president of the School of Islamic and Social Sciences (SISS), which later became the Graduate School of Islamic and Social Sciences (GSISS); president of the Fiqh Council of North America, holder of the Imam AlShafi'i Chair in Islamic Legal Theory at Corboda University; founding member and president of the International Institute of Islamic Thought (IIIT); founder-member of the Council of the Muslim World League in Makkah; member of the Organization of Islamic Cooperation's Islamic Fiqh Academy in Jeddah; prolific writer; and world renowned Islamic scholar and expert in Islamic legal theory, jurisprudence, the principles of jurisprudence, Qur'anic sciences, and general Islamic thought - passed away on March 4, 2016, at Ireland's Shannon Airport while stopping over on his way from Cairo to Washington, DC.

An intellectual giant, friend, father, husband, and teacher, he leaves an immense void in the lives of many people. The Muslim world mourns his loss and is the poorer for it.

Shaykh Taha spent his life serving humanity and the truth, working tirelessly not only to elucidate the principles and methodology of Islamic jurisprudence, but also to remove many of the myths and prejudices that had, over time, become entwined with Muslim cultural traditions and gained a strong foothold in the Muslim mind.

Shaykh Taha always took account of Islam as it is being practised in the modern world. For example, his seminal work Apostasy in Islam (2011), a masterful example of historical and scriptural 
analysis, bravely disputes certain perspectives by placing its profound analysis firmly within a Qur'anic context so that the ongoing debate on this controversial issue could not be hijacked. His book The Ethics of Disagreement in Islam (1993), in a rather visionary sense, offered a methodology for resolving intra-Muslim conflicts.

Shaykh Taha always took into consideration the traditional approaches of studying the Islamic textual sciences and other fields of knowledge, giving primary importance to the Qur'an, followed by the Sunnah, the actions of the Sahabah, and, finally, scholastic interpretation. He not only understood his specialized subjects but also people, which enabled him to connect with Muslims residing in both the East and West, the young as well as the old. Thus it is little wonder that he became one of the contemorary Muslim world's great voices and that his life demands our notice and reflection.

Prophet Muhammed stated: "Who is the most favored of God? The one from whom the greatest good comes to His creatures."

Like all great scholars, Shaykh Taha shared a tremendous love of knowledge and this, when twinned with his even greater passion for faith, led him to try to achieve the highest standards in pursuit of both, a path that he traversed until his final days.

Born in Fallujah, Iraq, on May 12, 1935, he began studying at a very young age with some of Iraq's most prominent Islamic scholars. He continued his education at al-Azhar University, where he obtained a $\mathrm{PhD}$ in Islamic jurisprudence in 1973.

Always seeking to engage with people, even during his studies Shaykh Taha would look for ways to share his knowledge, as well as his spiritual and other insights, with others. Hence, by the 1950s and 1960s he was already teaching Islamic law, preaching, writing, delivering speeches, and involving himself in various activities. As a young man, he championed truth and reformation, empathized with the plight of those around him, and was not afraid to boldly oppose the socialist Ba'th Party, a stance that ultimately forced him to leave Iraq in 1969.

But far from dampening his spirits, this enabled him to come into his own intellectually by being appointed a lecturer at Riyadh's Imam Muhammad Ibn Saud Islamic University. He spent the next 
ten years teaching, completing his $\mathrm{PhD}$ in Cairo, and contributing to intitiatives there.

His spiritual and intellectual journey took him to the United States, where he continued to advance academically. His stature as a scholar kept on expanding, and his life took on a whole new dimension by becoming a platform for service and leadership as well as inspiring others. During this period of his life he became involved with the International Institute of Islamic Thought (IIIT). He enthusiastically promoted its vision by serving as a founding member of its Board of Trustees and as its president between 1988 and 1996.

This fortuituous encounter with the other founder members, a blessed meeting of people who shared a common outlook with regard to intellectual thought and reform, resulted in lifelong friendships based upon a deep mutual affection that only became stronger as the decades passed. Eminently practical, like his fellow colleagues he strove to marry intellectual exploration and religion with action.

Everyone who met Shaykh Taha instantly liked him and sought to cultivate his friendship. Soon his reach was global, for he could - and did - touch the hearts and elevate the minds of people everywhere. His large frame and gentle demeanor, often seen behind a desk with papers and books surrounding him on all sides, became the image that people have come to most associate with him.

People are remembered by the footprints they leave behind. Recounting IIIT's formation, AbdulHamid AbuSulayman describes Shaykh Taha's arrival as completing the Islamic legal dimension of the institute's work and thought. Nadia Mustafa recounts that when Shaykh al- 'Alwani took over direction of the research teams at IIIT's Cairo office in 1986, he completely transformed the teams by inspiring their members to adopt a much broader and global vision. Evidently Shaykh Taha left his mark wherever he went.

His contributions to IIIT began even earlier, specifically at a 1977 Islamic conference convened in Lugano, Switzerland, where over thirty scholars and thought leaders from all over the world gathered. This was where the decision was taken to establish the 
IIIT with its headquarters in the United States. Shaykh Taha brought an evolved juristic mind to all of his reformation endeavors and to his leadership role at IIIT.

Fully dedicated to the institute, his life shows how tirelessly he worked to serve its mission while simultaneously engaging in a wide range of other Islamic intellectual activities. While living in the United States he participated in numerous local and international scientific academies. Among these were the following: founding member of the Muslim World League in Jeddah, founding head of the Islamic Fiqh Council of North America, founding editor-in-chief of the Islämiyat al-Ma 'rifah journal, and founding head of SISS (later GSISS) in Leesburg, VA. In recognition of his highly developed acumen and growing prominence in Islamic intellectual thought, he was the first professor to be appointed to the joint program of Islamic studies offered by ten American universities in the Greater Metropolitan Washington, DC, area.

A life-long exemplary seeker of knowledge, he constantly pushed himself through reading, research, and discussions with others. He labored to develop the formulation, clarification, and articulation of his ideas. However, in all humility and sincerity he would change them when he saw fit to do so, for his attachment was not to those ideas but to the truth. His personal mission was to attain greater self-awareness in order to spread as widely as possible the essence of the Qur'an to the best of his ability. He lived to convey its message and the Sunnah in actionable terms for people in different cultures and localities so that they could live virtuous and successful lives.

It is no wonder, then, that Shaykh Taha sought to instruct and deliver knowledge, deeply rooted in his academic specialization, in the principles of jurisprudence and a jurisprudence of minorities (fiqh al-aqalliyāt), as most applicable to issues of modern Islamic thought and everyday concerns for people in different places. His lifelong concern was to enhance their lives directly and guide them to their own higher awareness and the truth. In pursuit of this goal, during the last decade of his life he devoted himself completely to reflecting upon the Qur'an. He published approximately ten books on related themes; a further eight books on his deepest reflections will be published soon. 
Shaykh Taha's approach could also be described as a "jurisprudence of reality," for he married higher-level academic thought with reason and basic common sense and then made his insights available so that people could both conceptually understand and apply them to their every day lives. One way in which he sought to do this was to use a categorization of the five fundamental aims of Islamic Law (maqāssid al-Sharī'ah) and implement it to deal with particular situations and concerns. His mastery of this approach to jurisprudence helped him found and lead the Fiqh Council of North America and establish a critically needed methodology to develop a fiqh for Muslim minorities.

Shaykh Taha was blessed with other qualities that enabled him to serve with such intensity. Many people were aware of his encyclopaedic memory, due to the astonishing ease with which he could quickly recall verses from the Qur'an, Prophetic Hadiths, and statements made by Muslim jurists, complete with their sources.

Whenever he was charged with issuing a fatwa, Shaykh Taha would diligently seek out input from people with expertise on the issue around which it revolved. He took equal care to consult Muslim scholars throughout the world, as well as Muslim minority communities. And thus his rulings were a communal interpretative effort, which illustrated the principle of consultation in practice.

Shaykh Taha, a man of incredible courage and strength who empathized with people and understood ordinary human existence, never backed down in the face of harsh criticism and backlash. Rather, he would continue the good fight by standing firm and resolute, voicing critical opinions and readaptations of thought that scholars sought to isolate from reform. His critiques and readaptations entailed a process of prudent textual interpretation, linking the texts to their temporal and geographical milieus, rethinking long-established legal rulings in light of the Qur'an's authority over other texts, and bolstering reinterpretations and his dissenting views from the majority with compelling evidence. In this context, he would quote Sürat al-Ahzāa 39: "Those who convey God's messages [to the world], and stand in awe of Him, and hold none but God in awe: for none can take count [of humanity's doings] as God does." Shaykh Taha traversed and demonstrated a fearless path to revealing the essence of the Qur'an. 
Shaykh Taha is greatly missed. He was an amazing individual whose like is seldom seen and whose intelligence, heart, and soul touched us in so many enduring ways. We count ourselves blessed to have known him.

May his son Ahmad and his daughters Zaynab and Ruqayya, as well as all family members, including his grandchildren, IIIT colleagues, and students find comfort that his essence, gifts, and love live on in each of them. May we choose to walk as firmly in the Prophet's footsteps as Shaykh Taha did. May our principels govern our actions as his did. May our passion for service in devotion to God and love of humanity blaze as brightly as his did, and may we submit ourselves to the truth as fearlessly as he did. We pay our deepest respects to Shaykh Taha Jabir al-'Alwani, to his life and legacy.

To God do we belong, and to Him shall we return. 